\title{
Assessing Nitrogen Status in Potted Geranium through Discriminant Analysis of Ground-based Spectral Reflectance Data
}

\author{
Yun-wen Wang \\ Department of Grassland Science, College of Animal Science and \\ Technology, China Agricultural University, Beijing 100193, The People's \\ Republic of China
}

\author{
Bruce L. Dunn ${ }^{1}$ \\ Department of Horticulture and Landscape Architecture, Oklahoma State \\ University, 358 Ag Hall, Stillwater, OK 74078-6027
}

\author{
Daryl B. Arnall \\ Department of Plant and Soil Sciences, Oklahoma State University, \\ Stillwater, OK 74078-6028
}

Additional index words. Pelargonium $\times$ hortorum, sensor technology, NDVI, SPAD

\begin{abstract}
Nitrogen (N) deficiencies can significantly reduce plant growth as well as flower quantity and quality. However, excessive $\mathbf{N}$ application leads to increased production costs and may cause water contamination as a result of runoff. Ground-based remote sensing of plant chlorophyll content offers the possibility to rapidly and inexpensively estimate crop $N$ status. The objective of this study was to test the reliability of three different Normalized Difference Vegetation Index (NDVI) measuring methods and SoilPlant Analyses Development (SPAD) chlorophyll meter values as indicators of geranium (Pelargonium $\times$ hortorum L.H. Bailey) N status. Two potted geranium cultivars, Rocky Mountain White and Rocky Mountain Dark Red, were supplied with $N$ at 0, 50, 100, and $200 \mathrm{mg} \cdot \mathrm{L}^{-1}$ levels, respectively. NDVI readings were measured at $45 \mathrm{~cm}$ above the canopy or media of individual plants or $45 \mathrm{~cm}$ above the canopy of a group of plants (four plants treated with the same $N$ rate were placed together). Significant correlations existed between indirect chlorophyll content measurements of SPAD values and NDVI readings regardless of four-pot group or single-pot measurements with $\mathrm{N}$ application rates and leaf $\mathrm{N}$ concentration. Using a cross-validation technique in discriminant analysis, $70.8 \%$ to $79.2 \%$ of sample cases were correctly categorized to the corresponding $N$ statuses including very deficient, deficient, and sufficient. Therefore, ground-based, non-destructive measurements of a chlorophyll meter and pocket NDVI unit were able to indicate N status. Considering that flower color can interfere with NDVI measurements, the chlorophyll meter may better determine $\mathbf{N}$ content when flowers are present.
\end{abstract}

Geraniums (Pelargonium spp.) are considered one of the most valuable potted plants produced in the United States with an estimated wholesale value of over $\$ 100$ million in 2010 for both seed and vegetatively produced

\footnotetext{
Received for publication 20 Oct. 2011.

We express our thanks to Mr. Stephen Stanphill for technical support in this research. We thank Dr. Janet Cole and Dr. Eric Stafne for kindly revising this manuscript before submission. We express our deep gratitude to the constructive advice from the three anonymous reviewers and Sun Gro Horticulture for the media donation.

Mention of trade name or commercial products is solely for the purpose of providing specific information and does not imply recommendation or endorsement by Oklahoma State University. Approved for publication by the director, Oklahoma Agricultural Experiment Station.

${ }^{1}$ To whom reprint requests should be addressed; e-mail bruce.dunn@okstate.edu.
}

plants (U.S. Department of Agriculture, 2010). Geraniums are typically grown under greenhouse conditions during winter and spring to respond to the high demand of spring commercial markets. Nitrogen use efficiency is of great concern in floriculture production under greenhouse conditions. Nitrogen fertilization requirements and plant tissue analysis standards for geraniums are available (Biamonte et al., 1993; Dole and Wilkins, 2005; Kofranek and Lunt, 1969; Krug et al., 2010; Mills and Jones, 1997; Price et al., 1997). However, monitoring $\mathrm{N}$ status based on leaf sampling and foliar analysis is timeconsuming and expensive. Because $\mathrm{N}$ is a major nutrient affecting plant chlorophyll content (Moorby and Besford, 1983), measuring chlorophyll concentration can be a useful index to assess the growth status and leaf $\mathrm{N}$ level of a plant (Seemann et al., 1987). Ground-based remote sensing of plant chlorophyll content and concentration offers the possibility of rapidly estimating crop $\mathrm{N}$ status and plant quality. For several horticultural crops, leaf $\mathrm{N}$ and chlorophyll concentration were found to be strongly correlated using a SPAD chlorophyll meter (Neilsen et al., 1995; Shaahan et al., 1999; Vos and Bom, 1993; Wang et al., 2004; Westerveld et al., 2003; Zanin and Sambo, 2006). In addition, the NDVI index is commonly used to differentiate plant properties such as chlorophyll, biomass, and plant nutrition (Raun et al., 1998). Use of an NDVI index is widely accepted in large-scale agronomic field production and some horticultural crops (Baghzouz et al., 2007; Bell et al., 2004; Carrillo, 2006; Clay et al., 2006; Eitel et al., 2008; El-Shikha et al., 2007; Peñuelas et al., 1994; Xiong et al., 2007) but has limited reports for greenhouse settings.

Based on assessing variability of reflectance measurements on plant growth and physiological conditions, using a statistical approach to extract useful information could be used to improve crop performance (Parihar et al., 2003). Discriminant analysis, a multivariate statistical classification model technique, is a powerful tool for selecting the predictor variables that allow the discrimination between different group levels and for classifying cases into different groups with a better than chance accuracy (Fernandez, 2010). It has been used successfully to separate $\mathrm{N}$ and water stresses in Helianthus annuus L. (Peñuelas et al., 1994), evaluate N status in Triticum aestivum L. (Filella et al., 1995), assess water and $\mathrm{N}$ stresses in Zea mays L. (Karimi et al., 2005a, 2005b; Strachan et al., 2002), and evaluate $\mathrm{N}$ and potassium deficiencies in Olea europaea L. orchards (Gómez-Casero et al., 2007). To our knowledge, there is no report about the detection of $\mathrm{N}$ status in potted geraniums to predict $\mathrm{N}$ fertilization needs using discriminant analysis.

In a previous experiment, Wang et al. (2012) found that NDVI and SPAD values can be used to reflect $\mathrm{N}$ status in geranium, and that cultivar and $\mathrm{N}$ rate can significantly affect flower quantity and quality. The objective of this study was to test the reliability of three NDVI measurements and SPAD values as indicators of geranium $\mathrm{N}$ status. Through assigning the aforementioned NDVI and SPAD values to predefined $\mathrm{N}$ levels based on leaf $\mathrm{N}$ content, we also conducted discriminant analysis with the purpose of integrating information as a tool to classify different $\mathrm{N}$ statuses.

\section{Materials and Methods}

Plant material and growth conditions. On 13 Dec. 2010, plugs (four to eight leaves) of two commercial geranium (Pelargonium $\times$ hortorum L.H. Bailey) cultivars, Rocky Mountain White and Rocky Mountain Dark Red, were obtained from Park Seed Co. (Greenwood, SC). Plugs were transplanted into standard (15.2-cm diameter and 1.35-L volume) pots with $\approx 0.35 \mathrm{~kg}$ Sun GR MetroMix media (Sun Gro Horticulture, Bellevue, WA) 4 weeks later. Both cultivars belong to the light-green leaves-type geraniums 
(Krug et al., 2010). A single plant was placed in each pot and plants were grown in the Department of Horticulture and Landscape Architecture Research Greenhouses at Stillwater, OK, under natural photoperiods. Temperature was set at $18 / 21{ }^{\circ} \mathrm{C}$ day/night with a maximum photosynthetic photon flux density of $500 \mu \mathrm{mol} \cdot \mathrm{m}^{-2} \cdot \mathrm{s}^{-1}$ at $1200 \mathrm{HR}$. Plants were hand-watered with tap water at a rate of $\approx 250 \mathrm{~mL}$ per pot per irrigation event to avoid excessive leaching. Starting 25 Feb. 2011, plants were fertigated with a solution containing 50,100 , or $200 \mathrm{mg} \cdot \mathrm{L}^{-1} \mathrm{~N}$ from urea ammonium nitrate (UAN) $(28 \mathrm{~N}-0 \mathrm{P}-0 \mathrm{~K})$ twice or three times per week for a total of 16 irrigations with fertilizer solution. Plants were irrigated with water as a control treatment $\left(0 \mathrm{mg} \cdot \mathrm{L}^{-1} \mathrm{~N}\right)$. Fertilizer solution was mixed in a plastic bucket and applied at the same volume as the water. Nitrogen treatments were designed to produce plants with $\mathrm{N}$ status ranging from deficient to excessive. The experiment consisted of eight treatments (two cultivars $\times$ four $\mathrm{N}$ levels) with 24 singlepot replications. Pots were arranged in a completely randomized design (CRD).

Normalized Difference Vegetation Index, Soil-Plant Analyses Development value, and nitrogen content determination. Normalized Difference Vegetative Index readings were collected 42 and $48 \mathrm{~d}$ after initial fertilizer treatment (DAT) using a NDVI pocket sensor (NTech Industries, Ukiah, CA) developed by Oklahoma State University. Two methods were used to evaluate the impact of plant canopy coverage on NDVI readings: 1) an individual plant was scanned (single-pot) $45 \mathrm{~cm}$ above the canopy; and 2) putting four adjacent pots of the same $\mathrm{N}$ treatment together (four-pot group) and sensing from $45 \mathrm{~cm}$ above the canopy to generate a larger, flatter, and more homogenous square area for measurements. For the first method, two sensor positions were used to evaluate changes in distances between the sensor and the plant surface on NDVI readings for single-pot measurements. One sensor position was placed $45 \mathrm{~cm}$ above the media of the pot (from media); the other one was placed $45 \mathrm{~cm}$ above the plant canopy (from canopy). Because the sensor had a circular field of view with a diameter of $11.8 \mathrm{~cm}$ wide at a $45-\mathrm{cm}$ height, the footprint of the sensor changed with plant growth on the media-based sensor position. For the second method, replications were reduced from 24 to six experimental units, and NDVI measurements were taken from the center of where the pots were grouped on four points arranged near the center of the scanned area, respectively. The field of view was the same from plant-canopy-level sensor position and four-pot group canopy measurements. At sampling dates 42 DAT and 48 DAT, individual plants were scanned from all 192 pots for NDVI readings including from both media and plant canopy and NDVI readings from six experimental units were determined for the four-pot group. To eliminate water status influences, all spectral measurements were made the day after plants were fertigated. To avoid interference of flower color, all pedicels were removed from each pot as they appeared. At 42 DAT and 48 DAT, leaf chlorophyll content was measured using a SPAD chlorophyll meter (SPAD-502; Konica Minolta, Japan). For each pot, measurements were collected from four mature leaves from the middle to upper portion of the plant and averaged.

At 48 DAT, 10 mature leaves were collected from each pot in the four-pot group for a total of 40 leaves combined. Leaf samples were analyzed for total $\mathrm{N}$ content as $\mathrm{g} \cdot \mathrm{kg}^{-1}$ dry matter (DM) (Soil, Water and Forage Analytical Laboratory, Oklahoma State University) using a LECO TruSpec Carbon and Nitrogen Analyzer (LECO Corporation, St. Joseph, MI).

Data analysis. Collected data were analyzed using SAS software (SAS/Stat procedures, Release 9.02; SAS Institute, Inc., Cary, $\mathrm{NC}$ ). Because the variances of the four $\mathrm{N}$ treatments were unequal in all three NDVI measurements at each measuring date by Bartlett's test and Levene's test, and the variance of $0 \mathrm{~N}$ rate was significantly greater than the variances of other three $\mathrm{N}$ rates, it affected the behavior of the $F$ test and the multiple comparisons. Therefore, for all of the NDVI readings at each measuring date, only the analysis of variance (ANOVA) within 50-, 100-, and 200-mg. $\mathrm{L}^{-1} \mathrm{~N}$ rates were determined. However, NDVI values measured at $0 \mathrm{~N}$ rate still represented a deficient $\mathrm{N}$ status. Because the variance of four $\mathrm{N}$ rates were equal, the ANOVAs were carried out with four treatments for leaf $\mathrm{N}$ content $\left(\mathrm{g} \cdot \mathrm{kg}^{-1}\right.$ $\mathrm{DM}$ ) and SPAD values at each measuring date. To simplify computation, we used mean values for each four-pot group (i.e., experimental unit) for all three NDVI readings and SPAD values at each measuring date. Analysis of variance using PROC GLM in SAS was used to calculate the effects of $\mathrm{N}$ and cultivar with six replicates on the parameters studied. Means of main effects and interactions were separated by protected least significant difference $(\alpha=0.05$ and 0.01$)$. Trend analyses were carried out with $\mathrm{N}$ rates for the linear and quadratic functions in SPAD, leaf $\mathrm{N}$ content, and all of the NDVI readings.

To prove the predictive ability of three NDVI measuring methods and SPAD value, linear regression analyses and significant tests were performed within them and also between $\mathrm{N}$ rates with them using the PROC REG procedure. All of the regressions were calculated over six replications of four $\mathrm{N}$ rates $(n=24)$ for each cultivar. The coefficient of determination $R^{2}$ was used to indicate the explained variance.

Discriminant analysis of the canopy spectral reflectance data was done using PROC DISCRIM in SAS. Nitrogen limits for leaf N sufficiency range from $2.91 \%$ to $3.51 \%$ for mature plants of light-green cultivars (Krug et al., 2010). The leaf $\mathrm{N}$ thresholds of three $\mathrm{N}$ status groups were defined as: 1) very deficient at $2.0 \%$ or less; 2) deficient, between $2.01 \%$ and $2.90 \%$; and 3 ) sufficient at $2.91 \%$ or greater. Based on the measurements, the DISCRIM procedure calculated different discriminate functions for categorizing observations into $\mathrm{N}$ status classes. The discriminant functions were generated from the samples for which $\mathrm{N}$ status was defined in two tested cultivars (count data). Then, functions could be applied to new spectral reflectance values but an unknown $\mathrm{N}$ status. The suitability of the discriminant functions for a given classification was compared using a cross-validation method, which involves the calculation of misclassification matrices. These were calculated by determining the number of wrongly classified $\mathrm{N}$ status group in any single category. Because the data sets were small, the "one data out" approach for cross-validation was repeatedly used.

\section{Results}

Effects of cultivars and nitrogen rates on Normalized Difference Vegetation Index, Soil-Plant Analyses Development, and leaf nitrogen content ( $g \cdot \mathrm{kg}^{-1}$ dry matter) values. At 42 DAT, NDVI values increased linearly with increasing $\mathrm{N}$ rate. Normalized Difference Vegetative Index values measured from a single pot at media base and on the four-pot group differed significantly between cultivars and $\mathrm{N}$ rates, whereas a statistical difference only occurred between cultivars for NDVI values on a single-pot canopy (Table 1). However, at 48 DAT, NDVI values measuring on a single pot at the media base and on a four-pot group showed a significant difference within $\mathrm{N}$ rates, but no significant differences were found between cultivars and $\mathrm{N}$ rates for NDVI values on a singlepot canopy (Table 1). The results indicated that NDVI value measuring from a singlepot canopy was less sensitive for detecting variations in $\mathrm{N}$ status than the other two measuring methods. Using the protected least significant difference value at the 0.05 level, significant differences for NDVI value on the four-pot group canopy were consistently detected between 50 and 100 or $200 \mathrm{mg} \cdot \mathrm{L}^{-1} \mathrm{~N}$ rates in 'Rocky Mountain White' and between 200 and 50 or 100 $\mathrm{mg} \cdot \mathrm{L}^{-1} \mathrm{~N}$ rates in 'Rocky Mountain Darker Red' both at 42 and 48 DAT. Meanwhile, measurements of NDVI on single-pot media only showed significant differences between 50- and 200-mg. $\mathrm{L}^{-1} \mathrm{~N}$ rates in 'Rocky Mountain White', and all $\mathrm{N}$ treatments were significantly different in 'Rocky Mountain Darker Red' at 42 DAT. However, only significant differences between 50- and 200$\mathrm{mg} \cdot \mathrm{L}^{-1} \mathrm{~N}$ rates were determined in both 'Rocky Mountain White' and 'Rocky Mountain Darker Red' at 48 DAT. Because the distance between the sensor and plant were reducing along plant growth, it is understandable that the measurements of NDVI value of a single pot on media-based position were interfered. Therefore, for NDVI value measurements on potted geranium, special consideration should be given to positioning of the sensor over the crop canopy and canopy architecture. With this in mind, the NDVI pocket sensor could also be used to detect $\mathrm{N}$ status of geranium plugs grown in plug trays 
Table 1. Response of two geranium cultivars to four nitrogen rates at 42 and $48 \mathrm{~d}$ after initial fertilizer treatment (DAT).

\begin{tabular}{|c|c|c|c|c|c|c|c|c|c|c|}
\hline \multirow[b]{2}{*}{ Cultivar } & \multirow[b]{2}{*}{$\begin{array}{l}\text { Nitrogen } \\
\text { rate } \\
\left(\mathrm{mg} \cdot \mathrm{L}^{-1}\right)\end{array}$} & \multicolumn{4}{|c|}{$42 \mathrm{DAT}$} & \multicolumn{5}{|c|}{$48 \mathrm{DAT}$} \\
\hline & & $\begin{array}{l}\text { NDVI of } \\
\text { single-pot } \\
\text { media }^{z}\end{array}$ & $\begin{array}{l}\text { NDVI of } \\
\text { single-pot } \\
\text { canopy }\end{array}$ & $\begin{array}{c}\text { NDVI on } \\
\text { 4-pot } \\
\text { group canopy }^{x}\end{array}$ & SPAD $^{\mathrm{w}}$ & $\begin{array}{l}\text { NDVI of } \\
\text { single-pot } \\
\text { media }\end{array}$ & $\begin{array}{l}\text { NDVI of } \\
\text { single-pot } \\
\text { canopy }\end{array}$ & $\begin{array}{c}\text { NDVI of } \\
\text { four-pot } \\
\text { group canopy }\end{array}$ & SPAD & $\begin{array}{c}\text { Leaf } N^{v} \\
\left(\mathrm{~g} \cdot \mathrm{kg}^{-1} \mathrm{DM}\right)\end{array}$ \\
\hline$\overline{\text { Rocky }}$ & 0 & $0.567 \pm 0.018$ & $0.534 \pm 0.033$ & $0.594 \pm 0.042$ & $33.5 \pm 0.9$ & $0.536 \pm 0.029$ & $0.498 \pm 0.047$ & $0.584 \pm 0.035$ & $30.6 \pm 2.0$ & $19.50 \pm 5.99$ \\
\hline Mountain & 50 & $0.732 \pm 0.009$ & $0.778 \pm 0.007$ & $0.827 \pm 0.011$ & $49.6 \pm 1.0$ & $0.703 \pm 0.013$ & $0.751 \pm 0.013$ & $0.819 \pm 0.014$ & $50.0 \pm 1.9$ & $30.02 \pm 0.76$ \\
\hline \multirow[t]{2}{*}{ White } & 100 & $0.739 \pm 0.006$ & $0.780 \pm 0.010$ & $0.837 \pm 0.006$ & $53.4 \pm 2.3$ & $0.716 \pm 0.018$ & $0.765 \pm 0.015$ & $0.832 \pm 0.011$ & $53.9 \pm 1.5$ & $33.45 \pm 0.37$ \\
\hline & 200 & $0.748 \pm 0.009$ & $0.790 \pm 0.012$ & $0.845 \pm 0.004$ & $59.2 \pm 2.0$ & $0.735 \pm 0.024$ & $0.783 \pm 0.026$ & $0.843 \pm 0.011$ & $58.8 \pm 2.6$ & $31.93 \pm 5.98$ \\
\hline Rocky & 0 & $0.519 \pm 0.050$ & $0.490 \pm 0.085$ & $0.550 \pm 0.070$ & $25.9 \pm 4.4$ & $0.475 \pm 0.066$ & $0.468 \pm 0.100$ & $0.537 \pm 0.076$ & $21.1 \pm 2.9$ & $17.82 \pm 5.83$ \\
\hline Mountain & 50 & $0.707 \pm 0.008$ & $0.769 \pm 0.008$ & $0.820 \pm 0.009$ & $42.6 \pm 2.2$ & $0.696 \pm 0.025$ & $0.759 \pm 0.034$ & $0.820 \pm 0.007$ & $43.5 \pm 1.9$ & $27.45 \pm 4.35$ \\
\hline \multirow[t]{2}{*}{ Dark Red } & 100 & $0.722 \pm 0.015$ & $0.772 \pm 0.014$ & $0.824 \pm 0.009$ & $46.4 \pm 2.5$ & $0.712 \pm 0.022$ & $0.761 \pm 0.029$ & $0.822 \pm 0.008$ & $45.9 \pm 1.6$ & $28.33 \pm 4.31$ \\
\hline & 200 & $0.739 \pm 0.010$ & $0.777 \pm 0.010$ & $0.838 \pm 0.007$ & $50.2 \pm 2.8$ & $0.728 \pm 0.015$ & $0.776 \pm 0.015$ & $0.838 \pm 0.008$ & $51.2 \pm 2.0$ & $33.22 \pm 2.39$ \\
\hline Cultivar & & $* * * * \mathrm{u}$ & $* *$ & $* *$ & $* * * *$ & NS & NS & NS & $* * * *$ & NS \\
\hline $\mathrm{N}$ rates & & $* * * *$ & NS & $* * * *$ & $* * * *$ & $* *$ & NS & $* * * *$ & $* * * *$ & $* * * *$ \\
\hline $\begin{array}{c}\text { Cultivar } \times \\
\mathrm{N} \text { rates }\end{array}$ & & NS & NS & NS & NS & NS & NS & NS & NS & NS \\
\hline $\operatorname{LSD}_{0.05}{ }^{\mathrm{t}}$ & & 0.0117 & 0.0121 & 0.0093 & 2.92 & 0.0238 & $\mathrm{~N} / \mathrm{A}^{\mathrm{s}}$ & 0.0118 & 2.44 & 0.505 \\
\hline \multirow[t]{2}{*}{$\operatorname{LSD}_{0.01}$} & & 0.0158 & 0.0163 & 0.0125 & 3.91 & 0.0320 & N/A & 0.0159 & 3.26 & 0.675 \\
\hline & & $\mathrm{L} * * * * \mathrm{r}$ & $\mathrm{L}^{*}$ & $\mathrm{~L} * * * *$ & $\mathrm{~L}^{* * * *} \mathrm{Q} * * * *$ & $\mathrm{~L}^{* * *}$ & N/A & $\mathrm{L} * * * *$ & $\mathrm{~L} * * * * \mathrm{Q}^{* * * *}$ & $\mathrm{~L}^{* * * *} \mathrm{Q} * * * *$ \\
\hline
\end{tabular}

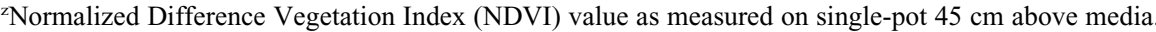

${ }^{y}$ NDVI value as measured on single-pot $45 \mathrm{~cm}$ above canopy.

${ }^{x}$ NDVI value as measured on four-pot group $45 \mathrm{~cm}$ above canopy.

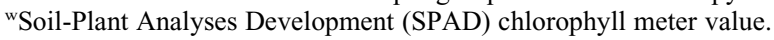

'Leaf nitrogen content; DM = dry matter.

${ }_{\mathrm{u}} \mathrm{N}, *, * * * * *, * * *$ Nonsignificant or significant at $P \leq 0.05, P \leq 0.01, P \leq 0.001$, or $P \leq 0.0001$, respectively. For all of the three NDVI readings at each measuring date, the analysis of variance within 50-, 100-, and 200-mg L ${ }^{-1} \mathrm{~N}$ rates were determined; for SPAD values and leaf $\mathrm{N}$ (\% DM), the analysis of variance were carried out within four nitrogen treatments.

${ }^{\mathrm{T}} \mathrm{LSD}_{0.05}=$ Fisher's protected least significant difference at $\alpha=0.05$ and $\alpha=0.01$, respectively.

${ }^{\mathrm{N}} \mathrm{N} / \mathrm{A}=$ not available.

r*,***,****Linear $(\mathrm{L})$ or quadratic $(\mathrm{Q})$ response at $P \leq 0.05, P \leq 0.001$, or $P \leq 0.0001$ level, respectively.

$\mathrm{DAT}=$ days after treatment; $\mathrm{N}=$ nitrogen.

after germination because canopy cover would limit background reflectance.

At 42 and 48 DAT, similar results occurred for SPAD values, because significant differences were found between cultivars and $\mathrm{N}$ rates, and SPAD values increased quadratically with increasing $\mathrm{N}$ rate from 0 to 200 $\mathrm{mg} \cdot \mathrm{L}^{-1}$ (Table 1). Except treatment means between 50 and $100 \mathrm{mg} \cdot \mathrm{L}^{-1} \mathrm{~N}$ rates in 'Rocky Mountain Darker Red' at 48 DAT, SPAD values could differentiate the $\mathrm{N}$ response within all four $\mathrm{N}$ rates clearly in each cultivar (Table 1). At 48 DAT, differences only occurred within $\mathrm{N}$ rates for leaf $\mathrm{N}$ content. In addition to the pair of treatment means between 50- and 200-mg. $\mathrm{L}^{-1} \mathrm{~N}$ rates in 'Rocky Mountain Darker Red', differences were detected between the $0 \mathrm{~N}$ rate and the other three $\mathrm{N}$ levels in each cultivar (Table 1). With increasing $\mathrm{N}$ rate, leaf $\mathrm{N}$ content increased quadratically.

Relationship between Normalized Difference Vegetation Index, Soil-Plant Analyses Development, and leaf nitrogen content $\left(\mathrm{g} \cdot \mathrm{kg}^{-1}\right.$ dry matter) values. At 42 and 48 DAT, coefficient of determination was higher for the SPAD meter than all three NDVI readings in both cultivars, and a strong linear relationship existed between all three NDVI readings and SPAD values among two cultivars (Table 2). At 48 DAT, the degree of linear fit $\left(R^{2}\right)$ between leaf $\mathrm{N}$ content with three NDVI measuring methods and SPAD value among two cultivars ranged from 0.486 to 0.672 ; they were significantly related.

Discrimination between nitrogen status. Sample size and some descriptive statistical
Table 2. Coefficients of determination $\left(R^{2}\right)$ of the linear regression relationships between measured parameters in two geranium cultivars $(\mathrm{n}=24)$.

\begin{tabular}{|c|c|c|c|c|c|}
\hline $42 \mathrm{DAT}$ & NDVI-media ${ }^{z}$ & NDVI-canopy & NDVI-four-pot ${ }^{\mathrm{x}}$ & SPAD $^{\mathrm{w}}$ & Leaf $\mathrm{N}^{\mathrm{v}}\left(\mathrm{g} \cdot \mathrm{kg}^{-1} \mathrm{DM}\right)$ \\
\hline & \multicolumn{5}{|c|}{ Rocky Mountain White } \\
\hline $\mathrm{N}$ rate $(\mathrm{ppm})$ & $0.533^{* * * * u}$ & $0.496 * * * *$ & $0.507 * * * *$ & $0.788 * * * *$ & ${ }^{\mathrm{t}}$ \\
\hline NDVI-soil & & $0.986^{* * * *}$ & $0.963^{* * * *}$ & $0.885^{* * * *}$ & - \\
\hline NDVI-canopy & & & $0.980^{* * * *}$ & $0.861 * * * *$ & - \\
\hline \multirow[t]{2}{*}{ NDVI-four-pot } & & & & $0.857 * * * *$ & 一 \\
\hline & \multicolumn{5}{|c|}{ Rocky Mountain Dark Red } \\
\hline $\mathrm{N}$ rate $(\mathrm{ppm})$ & $0.551 * * * *$ & $0.443 * * *$ & $0.486 * * *$ & $0.678 * * * *$ & 一 \\
\hline NDVI-soil & & $0.965^{* * * *}$ & $0.978 * * * *$ & $0.892 * * * *$ & - \\
\hline NDVI-canopy & & & $0.980 * * * *$ & $0.829 * * * *$ & - \\
\hline NDVI-four-pot & & & & $0.874 * * * *$ & - \\
\hline
\end{tabular}

48 DAT

$\mathrm{N}$ rate (ppm)

$0.571^{* * * *}$

$0.535^{* * * *}$

Rocky Mountain White

NDVI-soil

NDVI-canopy

NDVI-four-pot

SPAD

$0.528 * * * *$
$0.927 * * * *$
$0.970 * * * *$

$0.725 * * * *$

$0.891 * * * *$

$0.884 * * * *$

$0.898 * * * *$

$0.352 * *$

$0.609 * * * *$

$0.663 * * * *$

$0.637 * * * *$

$0.672 * * * *$

$\mathrm{N}$ rate (ppm)

$0.515 * * * *$

$0.448 * * *$
$0.974 * * * *$

Rocky Mountain Dark Red

NDVI-soil

NDVI-canopy

NDVI-four-pot

$0.484 * * *$
$0.966^{* * * *}$

$0.685 * * * *$

$0.547 * * * *$

$0.598 * * * *$

$0.486 * * *$

$0.567 * * * *$

$0.629 * * * *$

${ }^{2}$ Normalized Difference Vegetation Index (NDVI) value as measured on single-pot $45 \mathrm{~cm}$ above media

'NDVI value as measured on single-pot $45 \mathrm{~cm}$ above canopy.

${ }^{\mathrm{x}} \mathrm{NDVI}$ value as measured on four-pot group $45 \mathrm{~cm}$ above canopy.

wSoil-Plant Analyses Development (SPAD) chlorophyll meter value.

${ }^{\vee}$ Leaf nitrogen content; $\mathrm{DM}=$ dry matter.

$\mathrm{u}^{* *}, * * *, * * * *$ Significant at $P \leq 0.01, P \leq 0.001$, or $P \leq 0.0001$, respectively.

'Not performed.

$\mathrm{N}=$ nitrogen; DAT $=$ days after treatment.

parameters of leaf $\mathrm{N}$ content $\left(\mathrm{g} \cdot \mathrm{kg}^{-1} \mathrm{DM}\right)$ of each $\mathrm{N}$ status category classified based on leaf $\mathrm{N}$ content at a sampling date of $48 \mathrm{DAT}$ are presented (Table 3). Classification based on leaf $\mathrm{N}$ content resulted in unequal sample sizes among three $\mathrm{N}$ status categories (Table 
3). Overall classifications were from $87.5 \%$ to $91.7 \%$ for 'Rocky Mountain White' and from $75.0 \%$ to $87.5 \%$ for 'Rocky Mountain Dark Red' (Table 4). For cross-validation, the accuracy rates of NDVI on the four-pot group and SPAD values were the same. Accuracy rates for SPAD values were 79.2\% for 'Rocky Mountain White' and $70.8 \%$ for 'Rocky Mountain Dark Red', whereas the accuracy rates of the two NDVI measurements on a single pot were also the same at $70.8 \%$ for 'Rocky Mountain White' and $75.0 \%$ for 'Rocky Mountain Dark Red' (Table 4).

The classification matrix for crossvalidation is shown in Tables 5 and 6 . The values put both correctly classified and misclassified cases into the $\mathrm{N}$ status categories. Probabilities for classification were derived from the sample size of each $\mathrm{N}$ status category for discriminant analysis. For classification of sufficient $\mathrm{N}$ category, no errors occurred in the three NDVI readings for both 'Rocky Mountain White' and 'Rocky Mountain Dark Red', and the accuracy rate was 93.7\% for 'Rocky Mountain White' and was $84.6 \%$ for 'Rocky Mountain Dark Red' for SPAD values (Tables 5 and 6). However, to classify the very deficient categories for cross-validation data, the classification accuracy rates for NDVI values on the four-pot group and SPAD values were the same, reaching $60.0 \%$ for 'Rocky Mountain White' and $66.7 \%$ for 'Rocky Mountain Dark Red'. The predictive success rates for the NDVI values of a single pot from media basis and canopy basis were the same (only 20.0\%) for 'Rocky Mountain White' and were 50.0\% and $83.3 \%$, respectively for 'Rocky Mountain Dark Red' (Tables 5 and 6). The intermediate category between deficient and sufficient was difficult to correctly classify. For 'Rocky Mountain White', except the classification accuracy rates of SPAD values which were $33.4 \%$, no correct classifications were obtained for all NDVI readings (Table 5). For 'Rocky Mountain Dark Red', the classification accuracy rates of SPAD values and NDVI of a single pot at media basis were the same reaching $40.0 \%$ accuracy (Table 6 ). No correct classifications were obtained in the other two NDVI readings (Table 6). The proportion of deficient cases misclassified into the very deficient category or the sufficient category was different for each NDVI reading method, SPAD values, and over the two tested cultivars.

\section{Discussion}

For ornamental plants growing under greenhouse conditions, $\mathrm{N}$ requirement varies with plant age and type. Young plants and seedlings do best with low to medium $\mathrm{N}$ levels, whereas plants in a late-vegetative growth stage require moderately high levels. In this experiment, we kept plants in a vegetative growth stage by removing all pedicels from each pot as they appeared and controlled the volume of watering and fertigation at $\approx 250 \mathrm{~mL}$ per pot per irrigation event to
Table 3. Statistical descriptive parameters of predefined nitrogen status categories for two geranium cultivars.

\begin{tabular}{|c|c|c|c|c|c|c|c|c|c|c|}
\hline \multirow[b]{3}{*}{$\mathrm{N}$ status ${ }^{\mathrm{z}}$} & \multicolumn{10}{|c|}{ Leaf nitrogen content ( $\mathrm{g} \cdot \mathrm{kg}^{-1}$ dry matter) } \\
\hline & \multicolumn{5}{|c|}{ Rocky Mountain White } & \multicolumn{5}{|c|}{ Rocky Mountain Dark Red } \\
\hline & $\overline{n^{y}}$ & Mean & SD & Maximum & Minimum & $\mathrm{n}$ & Mean & SD & Maximum & Minimum \\
\hline$\overline{\mathrm{VD}}$ & 5 & 1.70 & 0.40 & 1.99 & 1.04 & 6 & 1.62 & 0.31 & 1.95 & 1.16 \\
\hline $\mathrm{D}$ & 3 & 2.70 & 0.18 & 2.90 & 2.56 & 5 & 2.61 & 0.29 & 2.84 & 2.21 \\
\hline $\mathrm{S}$ & 16 & 3.27 & 0.19 & 3.61 & 2.91 & 13 & 3.17 & 0.23 & 3.48 & 2.93 \\
\hline
\end{tabular}

${ }^{\mathrm{z}} \mathrm{VD}=$ very deficient; $\mathrm{D}=$ deficient; $\mathrm{S}=$ sufficient.

${ }^{\mathrm{y}} \mathrm{n}=$ sample size.

$\mathrm{N}=$ nitrogen.

Table 4. Summary of misclassification metrics obtained from DISCRIM procedure for two geranium cultivars $(n=24)$.

\begin{tabular}{llcc}
\hline \multirow{2}{*}{ Cultivar } & \multicolumn{1}{c}{ Sensor reading } & $\begin{array}{c}\text { Classification } \\
(\%)\end{array}$ & $\begin{array}{c}\text { Cross-validation } \\
(\%)\end{array}$ \\
\hline Rocky Mountain & NDVI four-pot group & 79.2 \\
White & NDVI single pot (soil) & 87.5 & 70.8 \\
& NDVI single pot (canopy) & 87.5 & 70.8 \\
& SPAD & 91.7 & 79.2 \\
Rocky Mountain & NDVI four-pot group & 87.5 & 70.8 \\
Dark Red & NDVI single pot (soil) & 75.0 & 75.0 \\
& NDVI single pot (canopy) & 87.5 & 75.0 \\
& SPAD & 79.2 & 70.8 \\
\hline
\end{tabular}

${ }^{\mathrm{z}}$ Normalized Difference Vegetation Index (NDVI) sensor readings taken $45 \mathrm{~cm}$ above media height (soil), above canopy height (canopy), and above canopy height for the four-pot group (four-pot).

${ }^{y}$ Soil-Plant Analyses Development (SPAD) chlorophyll meter value.

Table 5. Classification matrix (number of cases and percent in parenthesis) obtained from the discriminant analysis procedure for count and cross-validation using Normalized Difference Vegetation Index (NDVI) and Soil-Plant Analyses Development (SPAD) chlorophyll meter values for nitrogen status in potted geranium cv. Rocky Mountain White grown under greenhouse condition $(\mathrm{n}=24)$.

\begin{tabular}{|c|c|c|c|c|c|c|}
\hline \multirow[b]{3}{*}{ Sensor reading } & \multirow{3}{*}{$\begin{array}{l}\text { Classification } \\
\text { method }\end{array}$} & \multicolumn{5}{|c|}{$\mathrm{N}$ status $^{\mathrm{z}}$} \\
\hline & & \multirow[b]{2}{*}{ Actual } & \multicolumn{4}{|c|}{ Predicted } \\
\hline & & & VD & $\mathrm{D}$ & $\mathrm{S}$ & Total \\
\hline \multirow{6}{*}{$\begin{array}{l}\text { NDVI on four-pot } \\
\text { group }\end{array}$} & Count & VD & $3(60.0)$ & $1(20.0)$ & $1(20.0)$ & 5 \\
\hline & & $\mathrm{D}$ & $0(0.0)$ & $2(67.7)$ & $1(33.3)$ & 3 \\
\hline & & $\mathrm{S}$ & $0(0.0)$ & $0(0.0)$ & $16(100.0)$ & 16 \\
\hline & Cross-validation & VD & $3(60.0)$ & $1(20.0)$ & $1(20.0)$ & 5 \\
\hline & & $\mathrm{D}$ & $1(33.3)$ & $0(0.0)$ & $2(67.7)$ & 3 \\
\hline & & $\mathrm{S}$ & $0(0.0)$ & $0(0.0)$ & $16(100.0)$ & 16 \\
\hline \multirow{6}{*}{$\begin{array}{l}\text { NDVI of single pot } \\
\text { from media }\end{array}$} & Count & VD & $3(60.0)$ & $1(20.0)$ & $1(20.0)$ & 5 \\
\hline & & $\mathrm{D}$ & $0(0.0)$ & $2(67.7)$ & $1(33.3)$ & 3 \\
\hline & & $\mathrm{S}$ & $0(0.0)$ & $0(0.0)$ & $16(100.0)$ & 16 \\
\hline & Cross-validation & VD & $1(20.0)$ & $3(60.0)$ & $1(20.0)$ & 5 \\
\hline & & $\mathrm{D}$ & $2(66.7)$ & $0(0.0)$ & $1(33.3)$ & 3 \\
\hline & & $\mathrm{S}$ & $0(0.0)$ & $0(0.0)$ & $16(100.0)$ & 16 \\
\hline \multirow{6}{*}{$\begin{array}{l}\text { NDVI of single pot } \\
\text { from canopy }\end{array}$} & Count & VD & $4(80.0)$ & $0(0.0)$ & $1(20.0)$ & 5 \\
\hline & & $\mathrm{D}$ & $0(0.0)$ & $2(66.7)$ & $1(33.3)$ & 3 \\
\hline & & $\mathrm{S}$ & $0(0.0)$ & $0(0.0)$ & $16(100.0)$ & 16 \\
\hline & Cross-validation & VD & $1(20.0)$ & $3(60.0)$ & $1(20.0)$ & 5 \\
\hline & & $\mathrm{D}$ & $2(66.7)$ & $0(0.0)$ & $1(33.3)$ & 3 \\
\hline & & $\mathrm{S}$ & $0(0.0)$ & $0(0.0)$ & $16(100.0)$ & 16 \\
\hline \multirow[t]{6}{*}{ SPAD } & Count & VD & $3(60.0)$ & $1(20.0)$ & $1(20.0)$ & 5 \\
\hline & & $\mathrm{D}$ & $0(0.0)$ & $2(66.7)$ & $1(33.3)$ & 3 \\
\hline & & $\mathrm{S}$ & $0(0.0)$ & $0(0.0)$ & $16(100.0)$ & 16 \\
\hline & Cross-validation & VD & $3(60.0)$ & $1(20.0)$ & $1(20.0)$ & 5 \\
\hline & & $\mathrm{D}$ & $1(33.3)$ & $1(33.4)$ & $1(33.3)$ & 3 \\
\hline & & $\mathrm{S}$ & $0(0.0)$ & $1(6.3)$ & $15(93.7)$ & 16 \\
\hline
\end{tabular}

${ }^{\mathrm{z}} \mathrm{VD}=$ very deficient; $\mathrm{D}=$ deficient; $\mathrm{S}=$ sufficient.

$\mathrm{N}=$ nitrogen.

avoid excessive leaching. Because of relatively low plant $\mathrm{N}$ requirement and leaching fraction restriction, limited differences of leaf $\mathrm{N}$ concentration were observed within
50-, 100-, and 200-mg. $\mathrm{L}^{-1} \mathrm{~N}$ rates using UAN. Krug et al. (2010) concluded a sufficient range of $\mathrm{N}$ application in geranium was from 100 to $300 \mathrm{mg} \cdot \mathrm{L}^{-1} \mathrm{~N}$ fertilizer using 
Table 6. Classification matrix (number of cases and percent in parenthesis) obtained from the discriminant analysis procedure for count and cross-validation using Normalized Difference Vegetation Index (NDVI) and Soil-Plant Analyses Development (SPAD) chlorophyll meter values for nitrogen status in potted geranium cv. Rocky Mountain Dark Red grown under greenhouse condition $(\mathrm{n}=24)$.

\begin{tabular}{|c|c|c|c|c|c|c|}
\hline \multirow[b]{3}{*}{ Sensor reading } & \multirow{3}{*}{$\begin{array}{l}\text { Classification } \\
\text { method }\end{array}$} & \multicolumn{5}{|c|}{$\mathrm{N}$ status $^{\mathrm{z}}$} \\
\hline & & \multirow[b]{2}{*}{ Actual } & \multicolumn{4}{|c|}{ Predicted } \\
\hline & & & VD & $\mathrm{D}$ & $\mathrm{S}$ & Total \\
\hline \multirow[t]{6}{*}{ NDVI on four-pot group } & Count & VD & $4(66.7)$ & $1(16.7)$ & $1(16.6)$ & 6 \\
\hline & & $\mathrm{D}$ & $0(0.0)$ & $1(20.0)$ & $4(80.0)$ & 5 \\
\hline & & $\mathrm{S}$ & $0(0.0)$ & $0(0.0)$ & $13(100.0)$ & 13 \\
\hline & Cross-validation & VD & $4(66.7)$ & $1(16.7)$ & $1(16.6)$ & 6 \\
\hline & & $\mathrm{D}$ & $1(20.0)$ & $0(0.0)$ & $4(80.0)$ & 5 \\
\hline & & $\mathrm{S}$ & $0(0.0)$ & $0(0.0)$ & $13(100.0)$ & 13 \\
\hline \multirow{6}{*}{$\begin{array}{l}\text { NDVI of single pot } \\
\text { from media }\end{array}$} & Count & VD & $6(100.0)$ & $0(0.0)$ & $0(0.0)$ & 6 \\
\hline & & $\mathrm{D}$ & $1(20.0)$ & $2(40.0)$ & $2(40.0)$ & 5 \\
\hline & & $\mathrm{S}$ & $0(0.0)$ & $0(0.0)$ & $13(100.0)$ & 13 \\
\hline & Cross-validation & VD & $3(50.0)$ & $1(16.7)$ & $2(33.3)$ & 6 \\
\hline & & $\mathrm{D}$ & $1(20.0)$ & $2(40.0)$ & $2(40.0)$ & 5 \\
\hline & & $\mathrm{S}$ & $0(0.0)$ & $0(0.0)$ & $13(100.0)$ & 13 \\
\hline \multirow{6}{*}{$\begin{array}{l}\text { NDVI of single pot } \\
\text { from canopy }\end{array}$} & Count & VD & $5(83.3)$ & $0(0.0)$ & $1(16.7)$ & 6 \\
\hline & & $\mathrm{D}$ & $0(0.0)$ & $1(20.0)$ & $4(80.0)$ & 5 \\
\hline & & $\mathrm{S}$ & $0(0.0)$ & $0(0.0)$ & $13(100.0)$ & 13 \\
\hline & Cross-validation & VD & $5(83.3)$ & $0(0.0)$ & $1(16.7)$ & 6 \\
\hline & & $\mathrm{D}$ & $1(20.0)$ & $0(0.0)$ & $4(80.0)$ & 5 \\
\hline & & $\mathrm{S}$ & $0(0.0)$ & $0(0.0)$ & $13(100.0)$ & 13 \\
\hline \multirow[t]{6}{*}{ SPAD } & Count & VD & $5(83.3)$ & $0(0.0)$ & $1(16.7)$ & 6 \\
\hline & & $\mathrm{D}$ & $1(20.0)$ & $2(40.0)$ & $2(40.0)$ & 5 \\
\hline & & $\mathrm{S}$ & $0(0.0)$ & $0(0.0)$ & $13(100.0)$ & 13 \\
\hline & Cross-validation & VD & $4(66.7)$ & $1(16.7)$ & $1(16.6)$ & 6 \\
\hline & & $\mathrm{D}$ & $1(20.0)$ & $2(40.0)$ & $2(40.0)$ & 5 \\
\hline & & $\mathrm{S}$ & $0(0.0)$ & $2(15.4)$ & $11(84.6)$ & 13 \\
\hline
\end{tabular}

${ }^{\mathrm{z}} \mathrm{VD}=$ very deficient; $\mathrm{D}=$ deficient; $\mathrm{S}=$ sufficient

$\mathrm{N}=$ nitrogen.

$13 \mathrm{~N}-0.86 \mathrm{P}-10.8 \mathrm{~K}$ liquid feed. This $\mathrm{N}$ concentration range is similar to an application range of 46.4 to $139.2 \mathrm{mg} \cdot \mathrm{L}^{-1} \mathrm{~N}$ with UAN in our study. However, the upper and lower limits were established by analyzing the growth of plants over time using plant height, diameter, dry weight, and growth index (GI); flower quality traits were not considered (Krug et al., 2010). In our previous studies, using the same UAN fertilizer, at initial bloom stage ( 5 weeks after initial pedicel appearance), plants fertilized with $100 \mathrm{mg} \cdot \mathrm{L}^{-1} \mathrm{~N}$ or $200 \mathrm{mg} \cdot \mathrm{L}^{-1} \mathrm{~N}$ twice a week had a significantly bigger inflorescence size and had more flowers than 50 $\mathrm{mg} \cdot \mathrm{L}^{-1} \mathrm{~N}$ (Wang et al., 2012); however, only the leaf $\mathrm{N}$ content of $200 \mathrm{mg} \cdot \mathrm{L}^{-1} \mathrm{~N}$ application treatment was within a sufficient range referring to Krug et al. (2010). As a result of plant age, type, water management strategy, and quality assessment parameters, we recommend that optimum $\mathrm{N}$ fertilizer rate may vary in geranium. Therefore, reflectance-based nondestructive measurements could offer a potential in-season $\mathrm{N}$ management strategy for geranium plants and improve $\mathrm{N}$ use efficiency properly.

At the vegetative stage, the degree of linear fit between leaf $\mathrm{N}$ concentration and indirect chlorophyll content measurements such as SPAD values and NDVI readings regardless of four-pot group or single-pot measurements were limited $\left(R^{2}=0.486\right.$ to 0.672 ) for potted geranium. Based on the assignment of such NDVI and SPAD readings to the corresponding $\mathrm{N}$ status, the
However, NDVI tends to saturate as the plant canopy closes (Tremblay et al., 2011). Therefore, the range of NDVI values that may separate $\mathrm{N}$ deficiency from $\mathrm{N}$ surplus in potted geranium is quite narrow. In addition, the measurement of leaf $\mathrm{N}$ concentration, although sensitive to $\mathrm{N}$ status, still can be affected by plant maturity, plant biomass, and variations in $\mathrm{N}$ allocation between plant parts. In this study, of the total 48 observations from both tested cultivars, there were at least five observations on leaf $\mathrm{N}$ content that fell out of the "expected" range. Nevertheless, potted geranium grown under greenhouse conditions also offers some advantages to use such sensors in practice, whereas the well-controlled environmental conditions and a normalization production procedure could eliminate inference with soil properties, water supply, and weather effects. An in-season $\mathrm{N}$ management strategy is easily implemented by multiple fertigations. Further research is required to establish more clearly the critical $\mathrm{N}$ concentration curve and the N nutrition index (NNI) with respect to the vegetative and reproductive growth, which may be expressed with plant GI and flower quantity or quality index on specific cultivar type, respectively. Once $\mathrm{N}$ status reference curve is identified, it is important to valid the minimum deficiency of $\mathrm{N}$ that such sensors can be detected. Then an important issue is to determine an $\mathrm{N}$ application rate to correct the deficiency and to investigate the efficiency of recovery response and economic returns by changing a fixed $\mathrm{N}$ fertilization to a sensebased or need-based application.

In conclusion, our results clearly indicate plant-based diagnostic strategy used with a discriminant analysis procedure was partially successful with $70.8 \%$ to $79.2 \%$ correct $\mathrm{N}$ category detection. In particular, such sensors were not sensitive enough to identify the deficient category with leaf $\mathrm{N}$ content between $2.01 \%$ and $2.90 \%$ on a DM basis. As we noted, sufficient $\mathrm{N}$ level was produced by $\mathrm{N}$ supply of $50 \mathrm{mg} \cdot \mathrm{L}^{-1} \mathrm{~N}$ in this study; the relationships observed between leaf $\mathrm{N}$ content and SPAD or NDVI readings reached a plateau at excessive $\mathrm{N}$ rates, which indicated nonlinearity of relationships in the above-optimal range of $\mathrm{N}$ supplies. Meanwhile, inadequate numbers of observations within the deficiency category may influence the accuracy of discriminant functions for categorizing observations into $\mathrm{N}$ status classes. On measurement consideration, both NDVI and SPAD readings have some limitations. It has been reported for some crops that leaf chlorophyll content may vary with cultivar (Debaeke et al., 2006), growth stages (Ziadi et al., 2010), leaf thickness (Peng et al., 1993), sampling procedure (Olfs et al., 2005; Peterson et al., 1993), and deficiency of nutrients other than N (Masoni et al., 1996). Our results demonstrated that for NDVI value measurements on potted geranium, special consideration should be given to positioning of the sensor over the crop canopy and canopy architecture. Interference from underlying ground reflectance, especially for incomplete canopy cover, has been proposed as a weakness for NDVI readings (Hatfield et al., 2008). that the indirect chlorophyll content measurements such as SPAD values and NDVI readings have the potential to quantify the $\mathrm{N}$ nutrition status of potted geranium grown under greenhouse condition. Because putting four pots together has an advantage of generating adequate coverage to increase accuracy for the pocket sensor, NDVI readings on the four-pot group from canopy height tended to be more stable to detect variations in $\mathrm{N}$ status than the other two single-pot values. Considering that colors other than green can interfere with NDVI measurements, the SPAD chlorophyll meter might have an advantage in determining $\mathrm{N}$ content in geraniums when flowering.

\section{Literature Cited}

Baghzouz, M., D.A. Devitt, and R.L. Morris. 2007. Assessing canopy spectral reflectance of hybrid bermudagrass under various combinations of nitrogen and water treatments. Appl. Eng. Agr. 23:763-774.

Bell, G.E., B.M. Howell, G.V. Johnson, W.R. Raun, J.B. Solie, and M.L. Stone. 2004. Optical sensing of turfgrass chlorophyll content and

Biamonte, R.L., E.J. Holcomb, and J.W. White. 1993. Fertilization, p. 39-54. In: White, J.W. (ed.). Geraniums IV. Ball Publishing, Batavia, IL.

Carrillo, T. 2006. Normalized difference vegetative index, arthropod density, water and nitrogen interactions in ACALA 1517-99 cotton, Gossypium hirsutum (L.). PhD diss., New Mexico State University, Las Cruces, NM. tissue nitrogen. HortScience 39:1130-1132. 
Clay, D.E., K. Kim, J. Chang, S.A. Clay, and K. Dalsted. 2006. Characterizing water and nitrogen stress in corn using remote sensing. Agron. J. 98:579-587.

Debaeke, P., P. Rouet, and E. Justes. 2006. Relationship between the normalized SPAD index and the nitrogen nutrition index: Application to durum wheat. J. Plant Nutr. 29:75-92.

Dole, J.M. and H.F. Wilkins. 2005. Floriculture principles and species. 2nd Ed. Prentice Hall, Upper Saddle River, NJ.

Eitel, J., D.S. Long, P.E. Gessler, and E.R. Hunt. 2008. Combined spectral index to improve ground-based estimates of nitrogen status in dryland wheat. Agron. J. 100:1694-1702.

El-Shikha, D.M., P. Waller, D. Hunsaker, T. Clarke, and E. Barnes. 2007. Ground-based remote sensing for assessing water and nitrogen status of broccoli. Agr. Water Mgt. 92:183-193.

Fernandez, G. 2010. Statistical data mining using SAS applications. 2nd Ed. CRC Press, Boca Raton, FL.

Filella, I., L. Serrano, J. Serra, and J. Peñuelas. 1995. Evaluating wheat nitrogen status with canopy reflectance indices and discriminate analysis. Crop Sci. 35:1400-1405.

Gómez-Casero, M.T., F. López-Granados, J.M. Peña-Barragán, M. Jurado-Expósito, and L.G. García-Torres. 2007. Assessing nitrogen and potassium deficiencies in olive orchards through discriminate analysis of hyperspectral data. J. Amer. Soc. Hort. Sci. 132:611-618.

Hatfield, J.L., A.A. Gitelson, J.S. Schepers, and C.L. Walthall. 2008. Application of spectral remote sensing for agronomic decisions. Agron. J. 100:S117-S131.

Karimi, Y., S.O. Prasher, H. Mcnaim, R.B. Bonnell, P. Dutilleul, and P.K. Goel. 2005a. Classification accuracy of discriminate analysis, neural networks and decision trees for weed and nitrogen stress detection in corn. Trans. Amer. Soc. Agr. Eng. 48:1261-1268.

Karimi, Y., S.O. Prasher, H. Mcnaim, R.B. Bonnell, P. Dutilleul, and P.K. Goel. 2005b. Discriminant analysis of hyperspectral data for assessing water and nitrogen stresses in corn. Trans. Amer. Soc. Agr. Eng. 48:805-813.

Kofranek, A.M. and O.R. Lunt. 1969. A study of critical nutrient levels in Pelargonium hortorum cultivar 'Irene'. J. Amer. Soc. Hort. Sci. 94:204-207.

Krug, B.A., B.E. Whipker, I. McCall, and B. Cleveland. 2010. Geranium leaf tissue nutrient sufficiency ranges by chronological age. J. Plant Nutr. 33:339-350.

Masoni, A., L. Ercoli, and M. Mariotti. 1996 Spectral properties of leaves deficient in iron, sulphur, magnesium, and manganese. Agron. J. 88:937-943.

Mills, H.A. and J.B. Jones, Jr. 1997. Plant analysis handbook II: A practical sampling, preparation, analysis, and interpretation guide. Micro-Macro Publishing, Athens, GA.

Moorby, J. and R.T. Besford. 1983. Mineral nutrition and growth, p. 481-529. In: Lauchi, A. and R.L. Bieleski (eds.). Inorganic plant nutrition. Encycl. Plant Physiol. New Series. SpringerVerlag, Berlin, Germany.

Neilsen, D., E.J. Hogue, L.C. Herbert, P. Parchomchuk, and G.H. Neilsen. 1995. Use of rapid techniques for estimating the $\mathrm{N}$ status of fertigated apple trees. Acta Hort. 283:211-218.

Olfs, H.W., K. Blankenau, F. Brentrup, J. Jasper, A Link, and J. Lammel. 2005. Soil and plant-based nitrogen fertilizer recommendations in arable farming. J. Plant Nutr. Soil Sci. 168:414-431.

Parihar, J.S., S. Panigrahy, and A. Singh. 2003. Remote sensing and SGIS as a tool for precision farming in horticulture sector in India, p. 37-38. In: Singh, H.P., G. Singh, J.C. Samuel, and R.K. Pathak (eds.). Precision farming in horticulture. NCPAH, DAC/PFDC, CISH, Lucknow, India.

Peng, S., F.V. García, R.C. Laza, and K.G. Cassman. 1993. Adjustment for specific leaf weight improves chlorophyll meter's estimate of rice leaf nitrogen concentration. Agron. J. 85:987-990.

Peñuelas, J., J.A. Gamon, A.L. Fredeen, J. Merino, and C.B. Field. 1994. Reflectance indices associated with physiological changes in nitrogenand water-limited sunflower leaves. Remote Sens. Environ. 48:135-146.

Peterson, T.A., T.M. Blackmer, D.D. Francis, and J.S. Schepers. 1993. Using a chlorophyll meter to improve $\mathrm{N}$ management. Nebguide G931171A. Cooperative Extension Service, University of Nebraska, Lincoln, NE.

Price, G.H., G.C. Cresswell, and K.A. Handreck. 1997. Ornamentals, p. 464-504. In: Reuter, D.J. and J.B. Robinson (eds.). Plant analysis: An interpretation manual. CSIRO, Collingwood, Australia.

Raun, W.R., G.V. Johnson, H. Sembiring, E.V. Lukina, J.M. LaRuffa, W.E. Thomason, S.B. Phillips, J.B. Solie, M.L. Stone, and R.W. Whitney. 1998. Indirect measures of plant nutrients. Commun. Soil Sci. Plant Anal. 29: 1571-1581.

Seemann, J.R., T.D. Sharkey, J. Wang, and C.B. Osmond. 1987. Environmental effects on photosynthesis, nitrogen-use efficiency, and metabolite pools in leaves of sun and shade plants. Plant Physiol. 84:796-802.

Shaahan, M.M., A.A. El-Sayed, and A.A.A. Abou El-Nour. 1999. Predicting nitrogen, magnesium, and iron nutritional status in some perennial crops using a portable chlorophyll meter. Scientifica Hort. 82:339-348.

Strachan, I.B., E. Pattey, and J.B. Boisvert. 2002. Impact of nitrogen and environmental conditions on corn as detected by hyperspectral reflectance. Remote Sens. Environ. 80:213224.

Tremblay, N., E. Fallon, and N. Ziadi. 2011. Sensing of crop nitrogen status: Opportunities, tools, limitations, and supporting information requirements. HortTechnology 21:274-281.

U.S. Department of Agriculture. 2010. Floriculture crops 2010 summary. Sp Cr 6-1 (11). p. 23-24.

Vos, J. and M. Bom. 1993. Hand-held chlorophyll meter: A promising tool to assess the nitrogen status of potato foliage. Potato Res. 36:301-308.

Wang, Q., J. Chen, and Y. Li. 2004. Nondestructive and rapid estimation of leaf chlorophyll and nitrogen status of peace lily using a chlorophyll meter. J. Plant Nutr. 27:557-569.

Wang, Y., B.L. Dunn, D.B. Arnall, and P.-S. Mao. 2012. Use of an active canopy sensor and SPAD chlorophyll meter to quantify geranium nitrogen status. HortScience 47:45-50.

Westerveld, S.M., A.W. McKeown, C.D. ScottDupree, and M.R. McDonald. 2003. Chlorophyll and nitrate meters as nitrogen monitoring tools for selected vegetables in southern Ontario. Acta Hort. 627:259-266.

Xiong, X., G.E. Bell, J.B. Solie, M.W. Smith, and B. Martin. 2007. Bermudagrass seasonal responses to nitrogen fertilization and irrigation detected using optical sensor. Crop Sci. 47: 1603-1610.

Zanin, G. and P. Sambo. 2006. Using SPAD-meter in nitrogen fertilization of Rosa chinensis Jacq. var. mutabilis. HortScience 41:969-970.

Ziadi, N., G. Bélanger, A. Claessens, L. Lefebvre, N. Tremblay, A.N. Cambouris, M.C. Nolin, and L.-É. Parent. 2010. Plant-based diagnostic tools for evaluating wheat nitrogen status. Crop Sci. 50:2580-2590. 